\title{
SISTEM PENYEGARAN RUANGAN DARI ASAP ROKOK DAN GAS LPG BERBASIS MIKROKONTROLER ATMEGA
} 8535

\author{
Dasef Akhwandi, Anton Yudhana \\ Program Studi Teknik Elektro, Fakultas Teknologi Industri, Universitas Ahmad Dahlan \\ Kampus III UAD, JI. Prof. Dr. Soepomo, Janturan , Yogyakarta 55161 \\ e-mail: dasef22@gmail.com, eyudhana@ee.uad.ac.id
}

\begin{abstract}
Cigarette smoke is the most common cause of air pollution material, especially in a room that is very disturbing and impact on health. According to the RI Health Department people who inhale the smoke will cause damage to the lungs, heart disease, and the children will experience a cough, runny nose, and sore throat and lung disease are higher. Cigarette smoke contains chemicals that are more than four thousand chemicals. The elements contained may cause damage to cell DNA. Another thing that is no less harmful that LPG gas which for some people is an alternative energy that is used for various purposes, because of the low price and ease of use and efficient. But there is a negative impact when using LPG gas in the house. Leakage of gas cylinders is a problem that is often found because it will cause a fire if they are not directly addressed. Safety devices need to be designed from exposure to secondhand smoke and leakage of LPG gas. draft air refresher tool of smoke and gas LPG microcontroller-based sensor ATMega 8535 with MQ-9 through the creation phase traps (hardware) and software (software). The hardware consists of a box that is the prototype of the room and there is a sensor MQ-9 for detecting smoke and gas LPG, microcontroller ATMega8535 as controller, buzzer as a warning that there is detected smoke and LPG as well as the fans who will be active in order to dispose of cigarette smoke and LPG gas from indoors to outdoors. The final results of this study indicate that it has successfully created a prototype tool air refresher from smoke and gas LPG using a sensor MQ-9 that would detect levels of indoor air, 100 to 1000 for a smoke and 100 to 10000 to LPG gas, and will be displayed on the LCD in ppm. When the indoor air levels reach 300 ppm, the buzzer will be activated and the $D C$ fan will remove indoor air to the outside, to indoor levels back to normal.
\end{abstract}

Keywords: tobacco smoke; gas; LPG; MQ-9; microcontroller ATMega8535; fans DC; buzzer; LCD.

\begin{abstract}
Abstrak
Asap rokok merupakan bahan penyebab terbanyak pencemaran udara terutama didalam ruangan yang sangat mengganggu dan berdampak pada kesehatan. Menurut DEPKES RI orang yang menghirup asap rokok akan menyebabkan kerusakan paru-paru, penyakit jantung, dan pada anakanak akan mengalami batuk, pilek, dan radang tenggorokan serta penyakit paru-paru lebih tinggi. Asap rokok memiliki kandungan bahan kimia yang lebih dari empat ribu bahan kimia. Unsur yang terkandung tersebut bisa menyebabkan kerusakan pada sel DNA. Hal lain yang tidak kalah membahayakan yaitu gas LPG yang bagi sebagian orang merupakan energi alternatif yang digunakan untuk berbagai keperluan, karena harga yang murah dan penggunaan yang mudah serta efisien. Namun ada dampak negatif ketika menggunakan gas LPG di dalam rumah. Kebocoran tabung gas adalah masalah yang sering ditemukan karena akan menimbulkan kebakaran apabila tidak langsung ditangani. Perlu dirancang alat pengaman dari paparan asap rokok dan kebocoran gas LPG. rancangan alat penyegaran udara dari asap rokok dan gas LPG berbasis mikrokontroler ATMega 8535 dengan sensor MQ-9 ini melalui tahap pembuatan perangkap keras (hardware) dan perangkat lunak (software). Perangkat keras terdiri dari kotak yang merupakan prototype ruangan dan terdapat sensor MQ-9 untuk mendeteksi asap rokok dan gas LPG, mikrokontroler ATMega8535 sebagai pengendali, buzzer sebagai
\end{abstract}

Sistem Penyegaran Ruangan dari Asap Rokok dan Gas LPG Berbasis Mikrokontroler (D.Akhwandi) 
Jurnal IImu Teknik Elektro Komputer dan Informatika (JITEKI)

Vol. 3, No. 1, Juni 2017

peringatan dini bahwa ada terdeteksi asap rokok dan gas LPG serta kipas yang akan aktif guna membuang asap rokok dan gas LPG dari dalam ruangan ke luar. Hasil akhir dari penelitian ini menunjukkan bahwa telah berhasil dibuat prototype alat penyegaran udara dari asap rokok dan gas LPG menggunakan sensor MQ-9 yang akan mendeteksi kadar udara dalam ruangan, 100 sampai 1000 untuk asap rokok dan 100 sampai 10000 untuk gas LPG, dan akan ditampilkan pada LCD dalam satuan ppm. Ketika kadar udara dalam ruangan mencapai 300 ppm maka buzzer akan aktif dan kipas DC akan membuang udara dalam ruangan ke luar, sampai kadar dalam ruangan menjadi normal kembali.

Kata Kunci : asap rokok; gas LPG; MQ-9; Mikrokontroler ATMega8535; Kipas DC; Buzzer, LCD.

\section{Pendahuluan}

Pencemaran udara dalam ruangan terutama rumah sangat berbahaya bagi kesehatan manusia, karena pada umumnya orang lebih banyak menghabiskan waktu untuk melakukan kegiatan di dalam rumah sehingga rumah menjadi sangat penting sebagai lingkungan mikro yang berkaitan dengan risiko dari pencemaran udara. Menurut data departemen kesehatan RI melaporkan adanya hubungan kausal antara penggunaan rokok dengan terjadinya berbagai penyakit kanker, penyakit jantung, penyakit sistem pernapasan, penyakit gangguan reproduksi dan kehamilan [1]. Risiko berbagai penyakit tersebut disebabkan pada setiap batang rokok yang mengandung lebih dari 4.000 bahan kimia toksik dan 43 bahan penyebab kanker [4].

Hal lain yang dapat membahaykan bagi manusia adalah kebocoran gas LPG. Sejak kompor berbahan bakar gas LPG (Liquid Petrolium Gas) semakin marak di indonesia, penggunaan tabung gas LPG pun ikut melambung. Selain karena harga yang terjangkau, bahan bakar gas juga dianggap lebih efisien dan ramah lingkungan. Namun ada dampak negatif yang ditemukan ketika menggunakan gas LPG di dalam rumah, yakni perasaan takut terjadi kebocoran tabung gas [5][7]. Kebocoran tabungan gas bukanlah masalah sepele. Kebocoran tabung gas dapat menyebabkan ledakan tabungan yang disertai semburan api, hal ini tentu akan beresiko timbulnya kebakaran. Tidak hanya itu kebocoran gas juga dapat menimbulkan dampak negatif pada kesehatan ketika gas tersebut terhirup. Dampak menghirup gas LPG terjadi seperi berikut: sulit bernapas, tubuh lemas, mual, pusing, gagal jantung. Di negara maju diperkirakan angka kematian pertahun karena pencemaran udara dalam ruang rumah sebesar $67 \%$ di perdesaan dan sebesar $23 \%$ di perkotaan, sedangkan di negara berkembang angka kematian terkait dengan pencemaran udara dalam ruang rumah daerah perkotaan sebesar $9 \%$ dan di daerah pedesaan sebesar $1 \%$, dari total kematian.

\section{Metode Penelitian}

\subsection{Perancangan Sistem}

Dalam perancangan ini terdiri dari dua perangkat, yaitu perangkat keras (hardware) dan perangkat lunak (software). Perangkat keras berupa rangkaian elektronika yang terdiri dari mikrokontroler, dan rangkaian sensor. Perangkat lunak yang digunakan adalah program assembly. Agar mempermudah dalam melakukan pembahasan dan pembaca dalam memahami kinerja rancangan alat, maka dapat dilihat pada Gambar 1 blok sistem alat berikut:

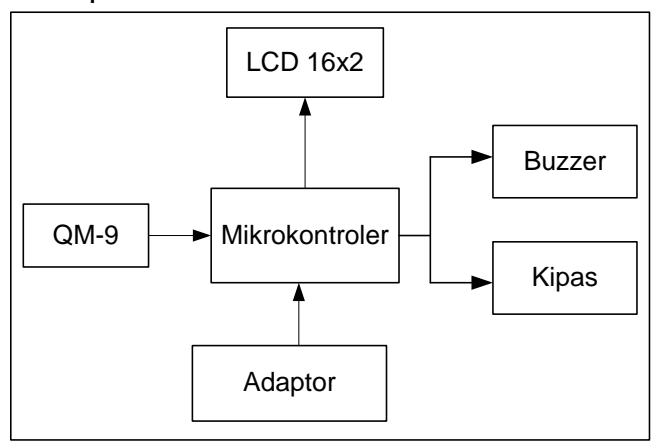

Gambar 1. Blok sistem alat 
Jurnal IImu Teknik Elektro Komputer dan Informatika (JITEKI)

Vol. 3, No. 1, Juni 2017

Adapun flowchart sistem secara keseluruhan dapat dijelaskan pada Gambar 2. sebagai berikut:

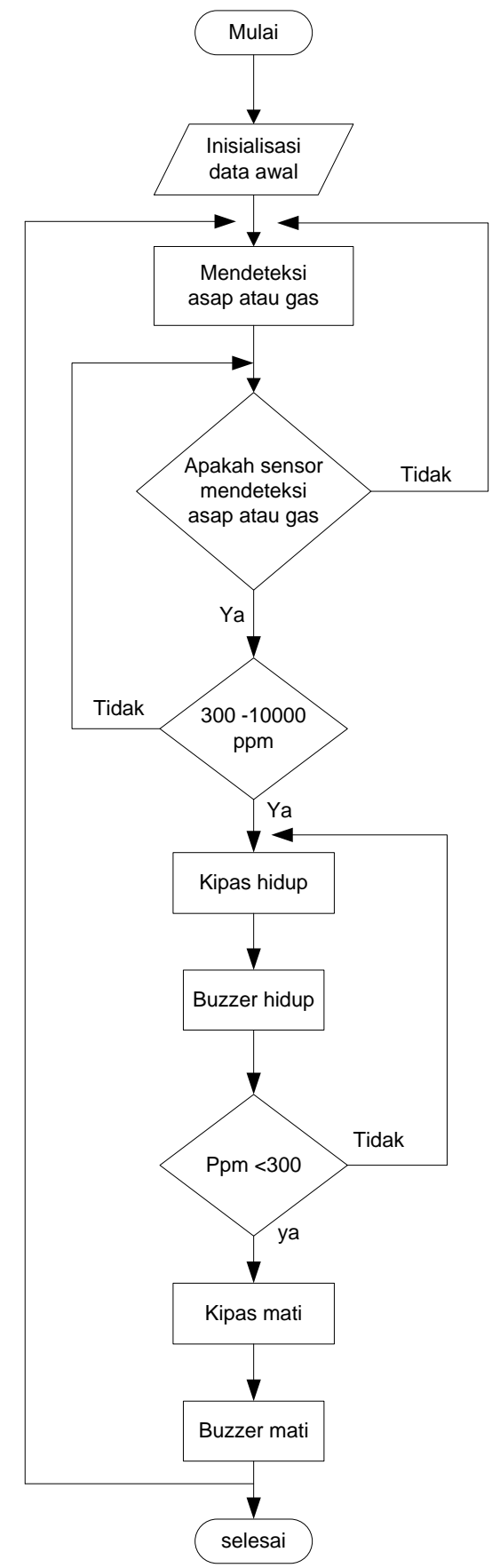

Gambar 2. Alur sistem pendeteksi asap rokok dan gas LPG

\subsection{Rangkaian Sistem Keseluruhan}

Rangkaian sistem mikrokontroler ATMega8535 yang ditunjukkan Gambar 3 merupakan sistem secara keseluruhan komponen yang digunakan sehingga berfungsi sebagai pengolah data dan pengendali alat pendeteksi asap rokok dan gas LPG. 
Jurnal IImu Teknik Elektro Komputer dan Informatika (JITEKI)

Vol. 3, No. 1, Juni 2017

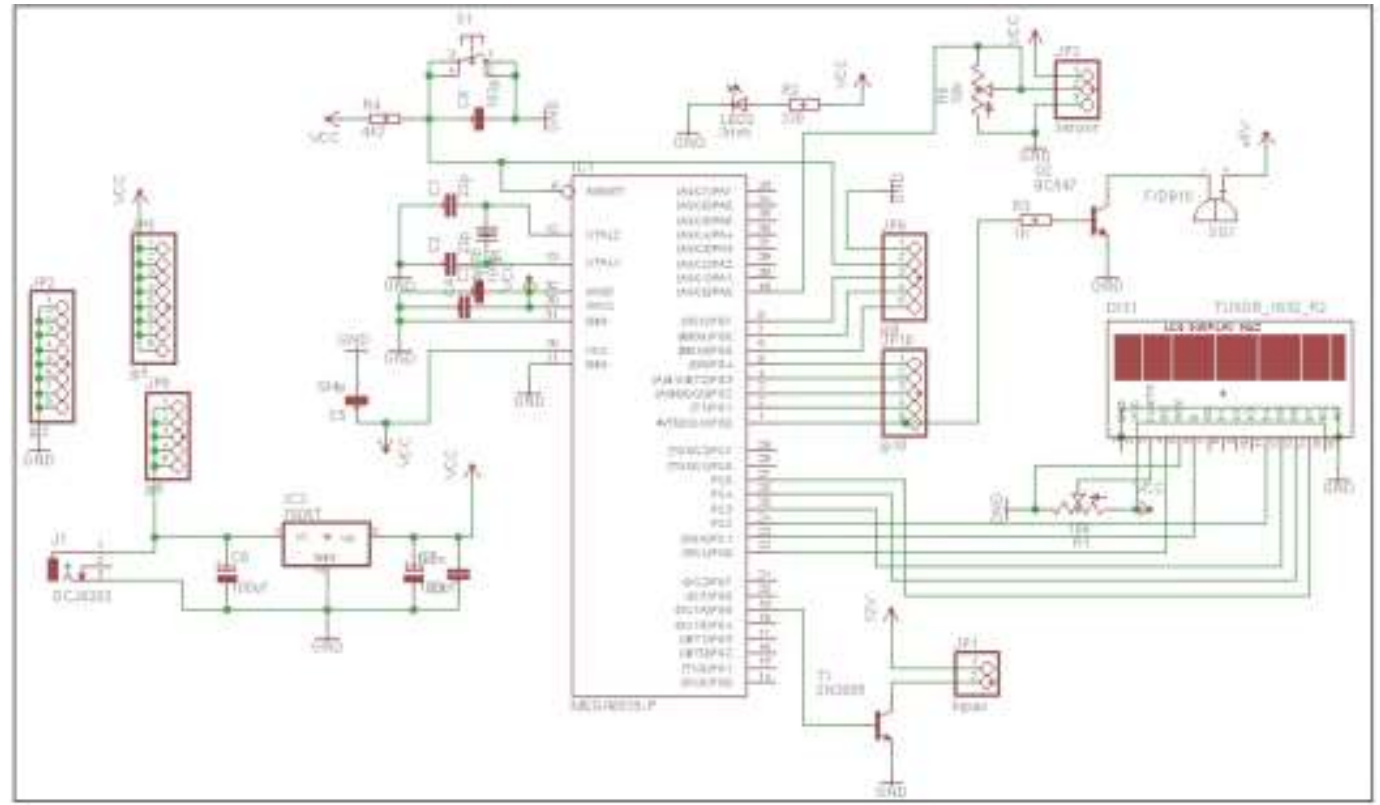

Gambar 3. Rangkaian sistem keseluruhan

Dari Gambar 3 diatas terlihat bahwa mirokontroler ATMega 8535 menjadi pusat pengolah data. Adapun port-port yang digunakan berupa port A0 sebagai masukan ADC dari sensor, port B0 sebagai pengontrol aktif dan nonaktifnya buzzer, port $\mathrm{C}$ merupakan output untuk menampilkan karakter pada LCD 16x2, dan port D5 merupakan output untuk mengontrol kipas.

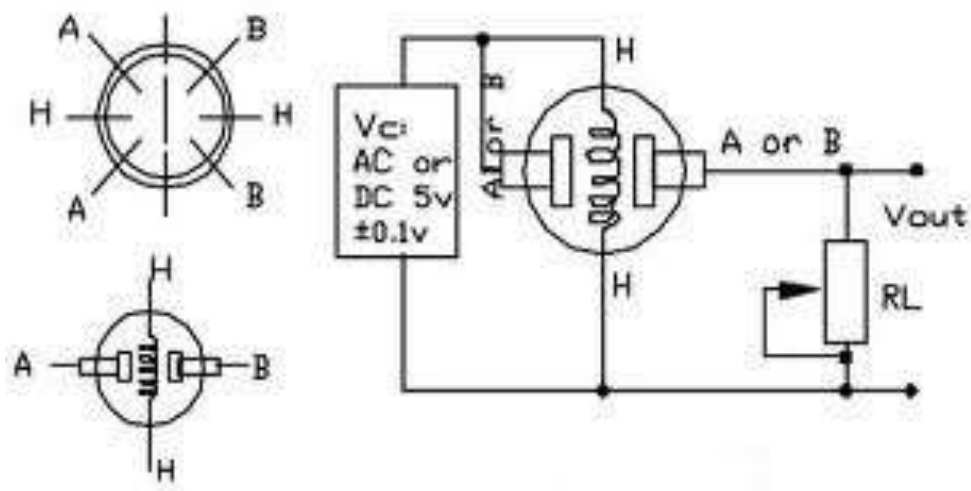

Gambar 4. Rangkaian sensor MQ-9

Gambar 4 menjelaskan rangkaian sensor memiliki 4 buah kaki, yaitu 2 kaki untuk mengaktifkan heater di kaki 3 dan 4, pada kaki 1 diberikan GND untuk heater, untuk output tegangan dari sensor ini ada pada kaki 2 yang langsung dihubungkan ke RL yang berupa variabel resistor [6][9].

\subsection{Mengkonversi ADC Ke PPM}

Konversi dari nilai tegangan ppm dilakukan pengambilan data dari grafik datasheet sensor mengenai Rs/Ro terhadap kadar gas ppm yang ditunjukkan pada Gambar 5. 
Jurnal IImu Teknik Elektro Komputer dan Informatika (JITEKI)

Vol. 3, No. 1, Juni 2017

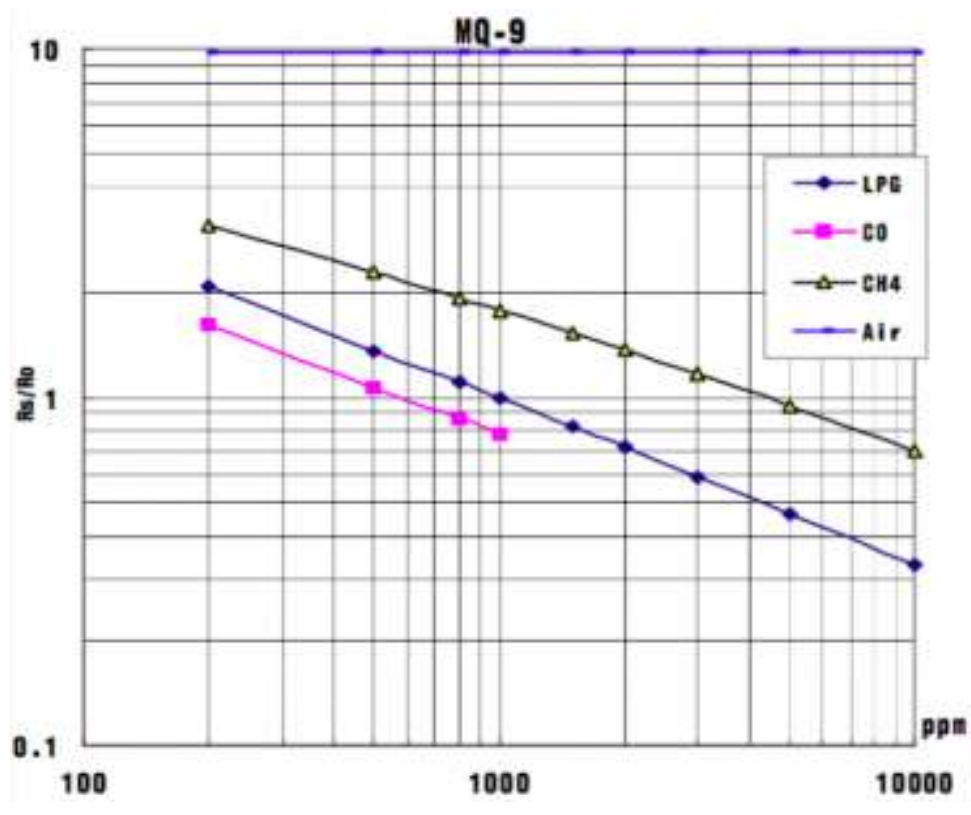

Gambar 5. karakteristik MQ-9

Langkah selanjutnya yaitu menghitung nilai Ro untuk mendapatkan nilai Rs/Ro. Nilai Ro dan Rs didapat melalui rumus berikut.

$$
R o=\frac{V c-V_{R L}}{V_{R L}} \times R L
$$

Ro adalah nilai resistansi sensor saat kondisi udara normal, tanpa tercampur asap rokok dan gas LPG . Nilai Vc merupakan nilai tegangan yang digunakan untuk mengaktifkan rangkaian sensor, VRL merupakan nilai tegangan diambil dari nilai minimal yang dikeluarkan sensor, $R L$ adalah variabel resistor yang digunakan.

$$
\begin{aligned}
& \mathrm{X}=\mathrm{VC}-\mathrm{VRL} \\
& \mathrm{Y}=\mathrm{X} / \mathrm{VRL} \\
& \mathrm{Rs}=\mathrm{Y}^{*} \mathrm{RL} \\
& \mathrm{D}=\mathrm{Rs} / \mathrm{Ro}
\end{aligned}
$$

Rs adalah nilai resistansi ketika sensor mendeteksi adanya asap rokok dan gas LPG. Sedangkan $\mathrm{D}$ adalah nilai dari Rs/Ro yang mana nilai $\mathrm{D}$ ini yang akan dionversikan kedalam ppm melalui rumus konversi yang didapat dari grafik pada mikrosoft exel. Yang perlu diingat yaitu $Y$ mewakili kadar gas dalam ppm dan X mewakili nilai Rs/Ro.

Dari proses konversi didapatkan rumus untuk mengubah nilai tegangan yang telah dirubah kedalam Rs dan Ro menjadi ppm. Rumusnya sebagai berikut.

$$
\begin{aligned}
& \left.\mathrm{ppm}=(28,211 /(\mathrm{Rs} / \mathrm{Ro}))^{1,937} \quad \text { (untuk asap rokok }\right) \\
& \mathrm{ppm}=(28,704 /(\mathrm{Rs} / \mathrm{Ro}))^{2,061} \quad(\text { untuk gas LPG })
\end{aligned}
$$


Jurnal IImu Teknik Elektro Komputer dan Informatika (JITEKI)

Vol. 3, No. 1, Juni 2017

\section{Hasil Dan Pembahasan}

3.1. Pengujian Sensor MQ-9

3.1.1. Pengujian Terhadap Asap Rokok

Tabel 1. Perubahan tegangan sensor mq 9 ketika mendeteksi asap rokok

\begin{tabular}{cccccc}
\hline No & Kadar Asap & Rs/Ro & Rs & Ro & Tegangan \\
\cline { 2 - 6 } & $(\mathrm{ppm})$ & $(\mathrm{ohm})$ & $(\mathrm{ohm})$ & $(\mathrm{ohm})$ & (Volt) \\
\hline 1 & 100 & 1,9 & 156666 & 82333,33 & 0,3 \\
\hline 2 & 200 & 1,77 & 146250 & 82333,33 & 0,32 \\
\hline 3 & 300 & 1,43 & 118205,12 & 82333,33 & 0,39 \\
\hline 4 & 400 & 1,22 & 101111,11 & 82333,33 & 0,45 \\
\hline 5 & 500 & 1,09 & 90000 & 82333,33 & 0,5 \\
\hline 6 & 600 & 0,99 & 80909,09 & 82333,33 & 0.55 \\
\hline 7 & 700 & 0,94 & 77719,29 & 82333,33 & 0.57 \\
\hline 8 & 800 & 0,85 & 70645,16 & 82333,33 & 0,62 \\
\hline 9 & 900 & 0,84 & 69626,86 & 82333,33 & 0,67 \\
\hline 10 & 1000 & 0,74 & 61428,57 & 82333,33 & 0,7
\end{tabular}

Dari data diatas didapatkan nilai tegangan yang didapat dari output sensor, kemudian dari nilai tegangan tersebut bisa didapatkan nilai Rs guna mendapatkan nilai Rs/Ro. Nilai Ro telah didapatkan sebelumnya yang merupakan nilai ketika sensor sebelum diberikan asap rokok. Dari data tabel diatas dapat dibuat grafik yang menandakan karakteristik dari sensor. Ditunjukkan pada Gambar 6 .

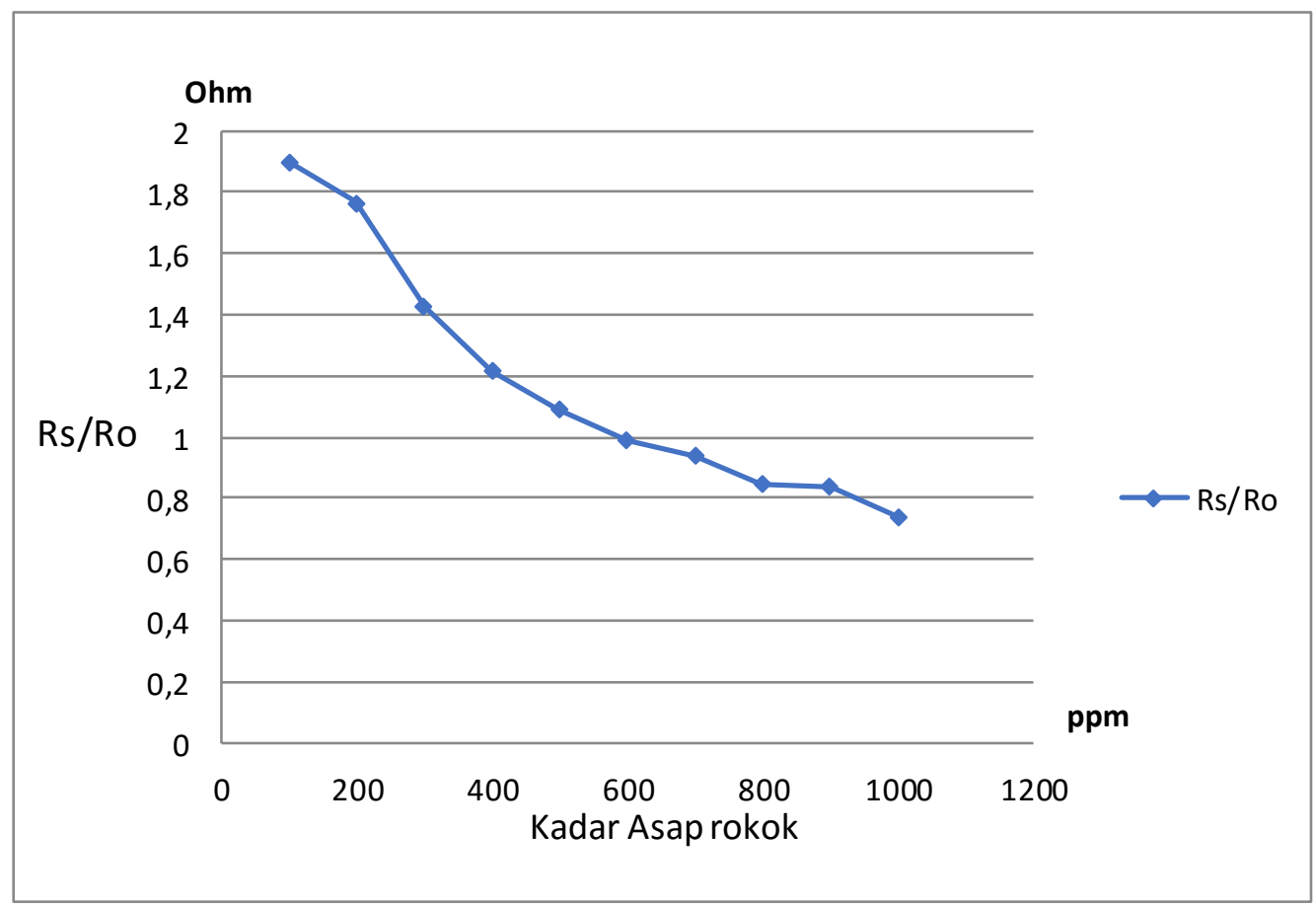

Gambar 6. Grafik hasil pengambilan data asap rokok 
Jurnal IImu Teknik Elektro Komputer dan Informatika (JITEKI)

Vol. 3, No. 1, Juni 2017

\subsubsection{Pengujian Terhadap Gas LPG}

Tabel 2. Perubahan tegangan sensor mq 9 ketika mendeteksi gas LPG

\begin{tabular}{cccccc}
\hline No & Kadar LPG & Rs/Ro & Rs & Ro & Tegangan \\
\cline { 2 - 6 } & $(\mathrm{ppm})$ & $(\mathrm{ohm})$ & $(\mathrm{ohm})$ & $(\mathrm{ohm})$ & (Volt) \\
\hline 1 & 100 & 2,91 & 240000 & 82333,33 & 0,2 \\
\hline 2 & 200 & 2,04 & 168571,43 & 82333,33 & 0,28 \\
\hline 3 & 300 & 1,77 & 132857,14 & 82333,33 & 0,35 \\
\hline 4 & 400 & 1,56 & 128888,89 & 82333,33 & 0,36 \\
\hline 5 & 500 & 1,4 & 115000 & 82333,33 & 0,4 \\
\hline 6 & 600 & 1,25 & 103636,36 & 82333,33 & 0,44 \\
\hline 7 & 700 & 1,18 & 96382,97 & 82333,33 & 0,47 \\
\hline 8 & 800 & 1,09 & 90000 & 82333,33 & 0,5 \\
\hline 9 & 900 & 1,02 & 82592,59 & 82333,33 & 0,54 \\
\hline 10 & 1000 & 0,96 & 79285,74 & 82333,33 & 0,56 \\
\hline 11 & 2000 & 0,69 & 54102,56 & 82333,33 & 0,78 \\
\hline 12 & 3000 & 0,57 & 45555,56 & 82333,33 & 0,9 \\
\hline 13 & 4000 & 0,48 & 40000 & 82333,33 & 1 \\
\hline 14 & 5000 & 0,43 & 35454,54 & 82333,33 & 1,1 \\
\hline 15 & 6000 & 0,42 & 34642,87 & 82333,33 & 1,12 \\
\hline 16 & 7000 & 0,38 & 31666,67 & 82333,33 & 1,2 \\
\hline 17 & 8000 & 0,36 & 30000 & 82333,33 & 1,25 \\
\hline 18 & 9000 & 0,34 & 28461,58 & 82333,33 & 1,3 \\
\hline 19 & 10000 & 0,32 & 27037,07 & 82333,33 & 1,35 \\
\hline & & & & &
\end{tabular}

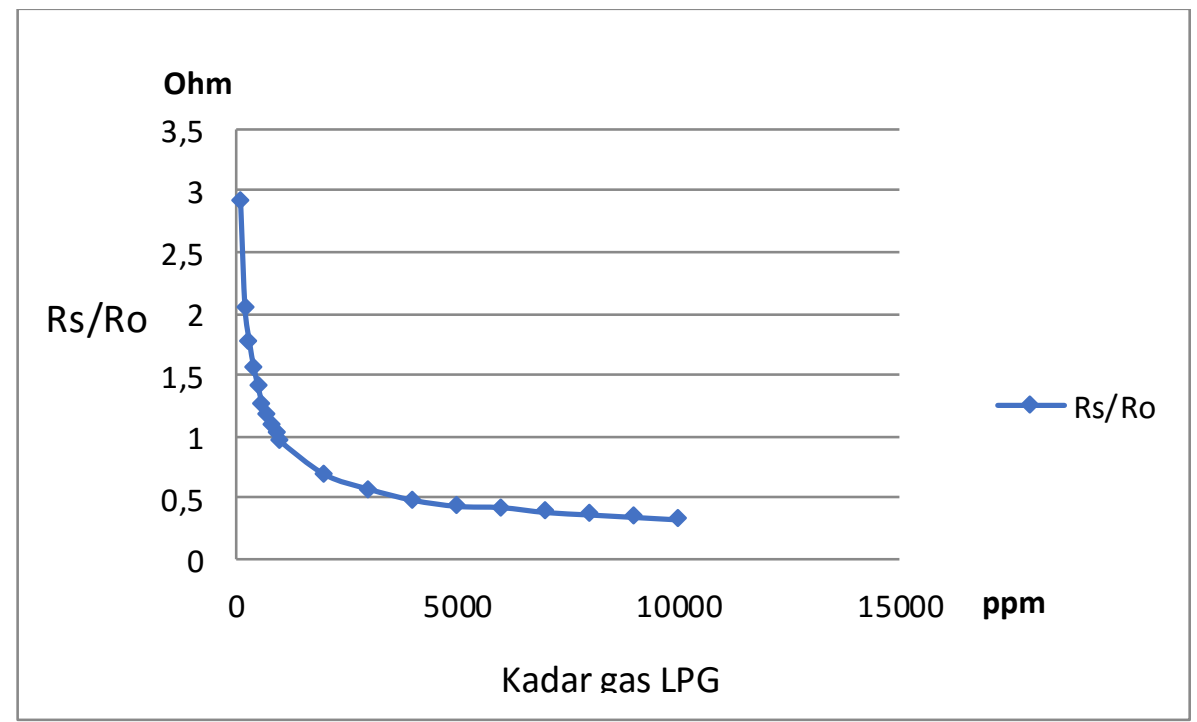

Gambar 7. Grafik hasil pengambilan data gas LPG 
Jurnal IImu Teknik Elektro Komputer dan Informatika (JITEKI)

Vol. 3, No. 1, Juni 2017

Tabel 2 merupakan hasil dari pengamatan yang dilakukan dengan menggunakan gas LPG yang diberikan dengan cara di semprotkan pada ruangan prototipe yang dibuat kemudian sensor akan mendeteksi sehingga menghasilkan ouput berupa kenaikkan nilai tegangan sehingga nilai yang dihasilkan seperti yang ditunjukkan pada kolom tegangan. Dari tegangan yang didapatkan maka peneliti dapat menemukan nilai Rs dengan menggunakan rumus yang ada. Sehingga dari nilai tersebut dapt diketahui nilai ppm seperti yang terlihat pada Gambar 7.

\subsection{Pengujian Kipas DC dan Buzzer}

Tabel 3. Hasil pengujian kipas dan buzzer

\begin{tabular}{ccccc}
\hline NO & $\begin{array}{c}\text { Kadar asap rokok } \\
(\mathrm{ppm})\end{array}$ & $\begin{array}{c}\text { Kadar gas LPG } \\
(\mathrm{ppm})\end{array}$ & Buzzer & Kipas \\
\hline 1 & 100 & 100 & Mati & Mati \\
\hline 2 & 200 & 200 & Mati & Mati \\
\hline 3 & 300 & 300 & Mati & Mati \\
\hline 4 & 400 & 400 & Hidup & Hidup \\
\hline 5 & 500 & 500 & Hidup & Hidup \\
\hline 6 & 600 & 600 & Hidup & Hidup \\
\hline 7 & 700 & 700 & Hidup & Hidup \\
\hline 8 & 800 & 800 & Hidup & Hidup \\
\hline 9 & 900 & 900 & Hidup & Hidup \\
\hline 10 & 1000 & 1000 & Hidup & Hidup \\
\hline
\end{tabular}

Tabel 3 adalah pengamatan yang dilakukan pada alat yang dibuat alat sudah berjalan seperti yang diharapkan seperti pada saat LCD menampilkan kadar udara dalam ruangan dengan kadar diatas 300 ppm maka buzzer dan kipas akan aktif, dan apabila udara dalam ruangan normal kembali maka buzzer dan kipas akan mati.

\subsection{Pengujian LCD}

LCD akan menampilkan hasil konversi dari ADC ke dalam bentuk ppm ditunjukkan pada Gambar 8.

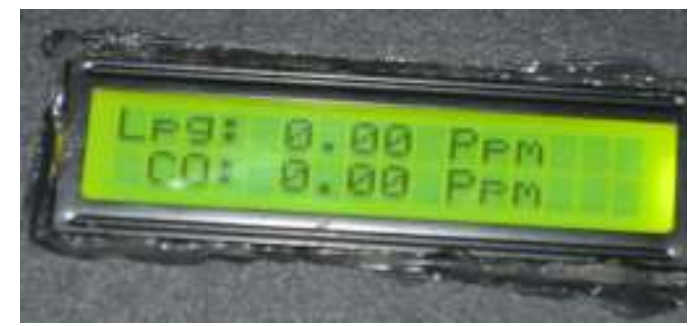

a

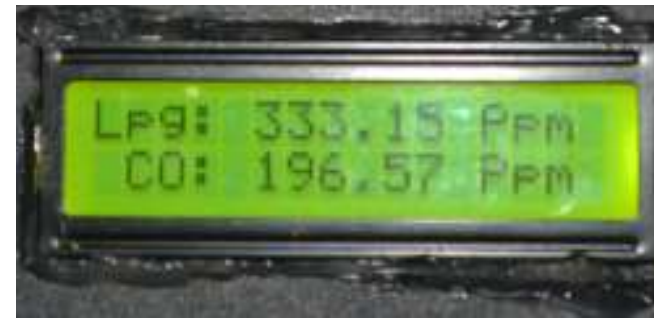

b

Gambar 8. Tampilan LCD sebelum sensor mendeteksi (a), sensor mendeteki adanya kadar asap dalam ruangan (b) 
Jurnal IImu Teknik Elektro Komputer dan Informatika (JITEKI)

Vol. 3, No. 1, Juni 2017

\subsection{Pengujian alat keseluruhan}

Dengan demikian maka alat tersebut telah berjalan sebagaimana mestinya karena dari hasil yang didapatkan Apabila terdeteksi asap rokok dan gas LPG, maka tegangan output pada sensor akan naik, sehingga konsentrasi gas akan menurun dan terjadi proses deoksidasi. Akibatnya permukaan dari muatan negatif oksigen akan berkurang, ketinggian permukaan sambungan penghalang pun akan ikut terjadi. Hal ini mengakibatkan penurunan resistansi sensor yang juga memiliki sebuah heater, yang berfungsi sebagai pembersih dari kontaminasi udara di dalam ruangan.

\section{Kesimpulan}

Setelah penulis melaksanakan penelitian dan membuat alat tugas akhir, penulis dapat menyimpulkan bahwa:

1. Sensor MQ-9 mampu mendeteksi adanya gas CO, LPG, metan dan memberikan perubahan tegangan keluaran berupa tegangan analog.

2. Sensor MQ-9 sensor akan mendeteksi gas tergantung dari tingkat kepekatan kadar gas tersebut. Semakin pekat kadar gas, maka semakin cepat terdeteksi oleh sensor.

3. Dibutuhkan waktu 15 detik dalam melakukan pemanasan sensor agar dapat digunakan.

4. Sistem sensor ini lebih sensitif apabila didekatkan dengan sumber obyek.

5. Sensor dapat mendeteksi asap rokok dari $100-1000$ ppm, dan gas LPG dari $100-10000$.

6. Kipas DC mampu membuang udara dari dalam ruangan baik itu asap rokok maupun gas LPG.

7. Buzzer dengan suara yang nyaring dapat menjadi tanda peringatan yang efektif.

8. Kadar yang ditampilkan pada LCD sudah dalam bentuk ppm.

\section{Referensi}

[1] Menteri kesehatan Republik Indonesia. (2011). Peraturan Menteri Kesehatan Republik Indonesia. Jakarta

[2] Heryanto, M.A. \& Adi, P.W. (2008). Pemrograman bahasa C untuk mikrokontroler ATMega8535. Yogyakarta: Andi.

[3] Sumardi. (2013). Mikrokontroler belajar AVR mulai dari nol. Yogyakarta: Graha ilmu.

[4] Barovih, G., Ardianto, R., Siregar, S.I., Pratama, S. (2016). Penerapan Teknologi Pendeteksi Kebocoran Liquified Petrolium Gas Berperingatan Alarm dan SMS. SISFOTENIKA. Vol.6, no.1.

[5] Triyandana, M.I., Muid, A., Rismawan, T. (2015). Pendeteksi Gas LPG dan Metana Dengan Sensor TGS 2610 dan Sensor TGS 261 Berbasis Mikrokontroler ATMega328P. Jurnal Coding, Sistem Komputer Untan. Vol 03, no.1, hal 11-12.

[6] Mauludin, dkk. (2016). MQ 2 Sebagai Sensor Anti Asap Rokok Berbasis Arduino dan Bahas C. Prosiding SNST. hal 260-265.

[7] Syarif, dkk. (3). Model Pengatur Kecepatan Kipas Menggunakan Sensor Asap Berbasis Arduino. Program study ilmu komputer FMIPA universitas pakuan.

[8] https://www.pololu.com/file/download/MQ9.pdf?file_id=0J314 (diakses 29 februari 2016)

[9] https://kangobing.files.wordpress.com/2012/06/rangkaian-mq-2.jpg (diakses 30 november 2016

[10] Yanuar, M. (2014). Membuat Detektor Gas LPG (Liquified Petroleum Gas) TGS2610. http://kursuselektronikaku.blogspot.co.id/2014/09/membuat-detektor-gas-lpg-liquified.html (Diakses 12 Desember 2015). 